Jurnal Health Sains: p-ISSN: 2723-4339 e-ISSN: 2548-1398

Vol. 3, No. 1, Januari 2022

\title{
PROFIL PENGGUNAAN OBAT HIPERTENSI PADA PASIEN BPJS RAWAT JALAN DI INSTALASI FARMASI DI RUMAH SAKIT X SUKABUMI
}

\author{
Wisma Ismaya, Rida Emelia \\ Politeknik Piksi Ganesha Bandung, Jawa Barat, Indonesia \\ Email:wisamasbm@gmail.com, emeliarida1310@gmail.com
}

\begin{tabular}{ll}
\hline INFO ARTIKEL & ABSTRAK \\
\hline Diterima & Telah dilakukan penelitian Profil Penggunaan Obat Hipertensi Pada \\
5 Januari 2022 & Pasien BPJS Rawat Jalan di Instalasi Farmasi di Rumah Sakit x \\
Direvisi & sukabumi jangka waktu 5 april s/d 31 mei 2021. Latar belakang dari \\
15 Januari 2022 & penelitian ini adalah meningkatnya prevalensi penderita penyakit kronis \\
Disetujui & dibanding penyakit non kronis dalam penelitian ini penyakit kronis \\
25 Januari 2022 & dikhususkan pada hipertensi. Adapun tujuan penelitian ini untuk \\
\hline Kata Kunci: & mendapatkan gambaran tentang profil penggunaan obat anti hipertensi \\
profil hipertensi; & pada pasien rawat jalan yang menggunakan BPJS dengan metode \\
pasien BPJS & penelitian yang digunakan deskriptif retrospektif yaitu dengan \\
& mengambil data sekunder yang bersumber dari resep pasien rawat jalan \\
& BPJS pada waktu yang telah ditentukan dikhususkan yang menderita \\
& hipertensi dan dikelompokan berdasarkan jenis kelamin, usia, golongan \\
& obat, jenis obat dan jumlah obat pada resep. Pasien rawat jalan BPJS \\
& yang menderita hipertensi terbanyak adalah laki - laki yaitu sebanyak \\
& 198 orang (53,37 \%), usia penderita adalah diatas 55 tahun (70.35\%), \\
& golongan anti hipertensi yang paling banyak digunakan adalah \\
& penghambat ACE (42,24\%) dan yang paling sedikit adalah nitrat (0,9\%), \\
& jenis anti hipertensi yang paling banyak diresepkan adalah amlodipine \\
& yaitu sebanyak 147 item (33,03\%) dan yang paling sedikit adalah \\
& diltiazem yaitu sebanyak 3 item (0,67\%), jumlah item anti hipertensi \\
& yang paling banyak diresepkan adalah satu item antihipertensi $(82,21 \%)$.
\end{tabular}

Keywords:

BPJS Patient;

Hypertention Profile

\section{ABSTRACT}

A profile study has been conducted on the use of hypertensi drugs in outpatient BPJS patient at the pharmacy installattion at hospital $X$ Sukabumi for a period of April 5 to May 31, 2021. The background of this study study is the increasing prevalencce of chronic disease patientd compared to non chronic deseases, in this study chronic disease is devoted to hypertension. The purpose of this study was to obtain an overview of the profile of the use of antihypertensive drugs in outpatient using BPJS with a retrospective descriptive research method, namely by taking secondary data sourced from prescription. BPJS outpatient at a predetermined time are specifically those who suffer from hypertention and are grouped by gender, age, drug class, type of drug and number of drugs on prescription. BPJS outpatients who suffer from hypertention the most are men, as many as 198 people (53,37\%), the age of the patient is above 55 years (70,3\%), the most widely used antihypertentive group is ACE inhibitors $(42,24 \%)$ and the least is nitrate $(0,9 \%)$. The most prescribed type of antihypertensive was amplodipine with 147 item (33,03\%) and the least was diltiazem with 3 item (0,67\%) the number

$\begin{array}{ll}\text { How to cite: } & \text { Ismaway. W. \& Emelia. R. (2022) Profil Penggunaan Obat Hipertensi pada Pasien BPJS Rawat } \\ & \text { Jalan di Instalasi Farmasi di Rumah Sakit X Sukabumi. Jurnal Health Sains 2(12). } \\ & \text { https://doi.org/10.46799/jhs.v3i1.399 } \\ \text { E-ISSN: } & 2723-6927 \\ \text { Published by: } & \text { Ridwan Institute }\end{array}$



antihypertensive $(82,21 \%)$.

\section{Pendahuluan}

Badan Penelitian dan Pengembangan

Kesehatan (Balitbangkes) Kementerian Kesehatan telah melakukan survei yang disebut Sample Registration Survey (SRS). Data dikumpulkan dari sampel yang mewakili Indonesia, meliputi 41.590 kematian sepanjang 2014, pada semua kematian itu dilakukan autopsi verbal, sesuai pedoman Badan Kesehatan Dunia (WHO) secara real time oleh dokter dan petugas terlatih. Data ini menunjukan 10 jenis penyakit paling sering menjadi penyebab kematian di Indonesia adalah penyakit: cerebrovaskular atau pembuluh darah di otak seperti pada pasien stroke, penyakit jantung iskemik, diabetes melitus dengan komplikasi, tubercolusis pernapasan, hipertensi atau tekanan darah tinggi dengan komplikasi, penyakit pernapasan khususnya penyakit paru obstruktif kronis (PPOK). Penyakit liver atau hati, akibat kecelakaan lalu lintas, pneumonia atau radang paru-paru, diare atau gastroenteritis yang berasal dari infeksi (Kuruvilla et al., 2018).

Penyakit tidak menular sering disebut sebagai penyakit kronis. Penyakit kronis didefinisikan sebagai kondisi medis atau masalah kesehatan yang berkaitan dengan gejala-gejala atau kecacatan yang membutuhkan penatalaksanaan jangka panjang. Berdasarkan data WHO, prevalensi penyakit kronis di dunia ini mencapai $70 \%$ dari kasus menyebabkan kematian presentse ini akan meningkat dari tahun ke tahun.

Diperkirakan pada tahun 2030 sekitar 150 juta orang akan terkena penyakit kronis. Di berbagai negara yang termasuk negara berkembang, peningkatan penyakit ini terjadi secara cepat dan memberikan dampak yang sangat signifikan pada sisi sosial, ekonomi dan kesehatan. Permasalahannya adalah sekitar 80 persen dari penyakit tidak menular ini justru terjadi pada negara-negara dengan pendapatan rendah atau yang sering disebut sebagai low and middle income countries (Kandhro et al., 2008).

Pemerintah sering dihadapkan pada berbagai masalah di bidang kesehatan, masalah yang cukup menjadi perhatian para ahli belakangan ini adalah assessment faktor risiko penyakit tidak menular. Salah satu hpenyebabnya adalah karena penyakit tidak menular sekarang ini memperlihatkan tendensi peningkatan. Peningkatan penyakit tidak menular ini banyak terjadi di negara berkembang karena perkembangan ekonominya mulai meningkat. Karena itulah maka terjadi peralihan bentuk penyakit yang harus dihadapi, yaitu dari penyakit menular dan infeksi menjadi penyakit tidak menular dan kronis. Proses tersebutlah yang kerap dikenal sebagai transisi epidemiologi (Bustan, 2007).

Salah satu jenis penyakit kronis yang ternyata menimbulakan angka kesakitan dan kematian yang tinggi adalah hypertensi. Data Riset Kesehatan Dasar (Riskesdas, 2013) menunjukkan bahwa 25,8 persen penduduk Indonesia mengidap hipertensi sedangkan tahun 2016 Survei Indikator Kesehatan Nasional (Sirkesnas) melihat angka tersebut meningkat jadi 32,4 persen.

Hipertensi menurut World Health Organization (WHO) adalah suatu kondisi dimana pembuluh darah memiliki tekanan darah tinggi (tekanan darah sistolik $\geq 140$ $\mathrm{mmHg}$ atau tekanan darah diastolik $\geq 90$ $\mathrm{mmHg}$ ) yang menetap. Tekanan darah adalah kekuatan darah untuk melawan tekanan dinding arteri ketika darah tersebut dipompa oleh jantung ke seluruh tubuh. Semakin tinggi tekanan darah maka semakin keras jantung bekerja (Organization, 2019).

Di rumah sakit $\mathrm{x}$ sukabumi, pasien hipertensi meningkat setiap tahunnya. Tahun 
2009 jumlah pasien hipertensi yang berobat jalan di rumah sakit x sukabumi 4.597 orang. Tahun 2010 meningkat menjadi 7.154 Orang (Erkan \& Arici Demirel, 2011).

Penyakit hipertensi yang telah mengalami komplikasi biasanya memerlukan obat dalam jumlah dan jenis yang banyak serta dibutuhkan terapi dan kombinasi obat, jadi potensi yang muncul dengan masalah terkait dengan obat bagi pasien menjadi sangat besar seperti interaksi obat dan efek samping.

\section{Hasil dan Pembahasan}

\section{A. Hasil Penelitian}

Berdasar hasil penelitian yang dilakukan penulis terhadap lembar sempel resep dan dan data rekam medis pasien peserta BPJS yang mengandung obat hipertensi di rumah sakit $\mathrm{x}$ sukabumi priode april-mei 2021 dapat dilihat sebagai berikut:

a. Karakter Pasien

Pasien yang dating berobat ke Rumah Sakit $\mathrm{x}$ sukabumi datang berbagai keluhan dan penyakit. Pasien

\section{Metode Penelitian}

(Sugiyono \& Kuantitatif, 2012), mengemukaan bahwa yang dimaksud dengan metode ilmiah untuk mendapatkan data dengan tujuan dan kegunaan tertentu. Penelitian ini merupakan penelitian deskriptif dengan pendekatan retrospektif yaitu dengan melihat kembali kemudian mengumpulkan dan mencatat resep pasien hipertensi rawat jalan pada bulan april-mei 2021 di rumah $\begin{array}{lll}\text { sakit } & X & \text { sukabumi }\end{array}$

hipertensi yang datang biasanya adalah pasien yang sudah kronis dan mengalami komplikasi lai seperti penyakit jantung.

Pasien BPJS penderita hipertensi cukup banyak jumlahnya baik laki laki, maupun perempuan dengan sebaran umur yang bervariasi, hal ini kita dapat lihat dari data yang ada pada table.

Tabel 1

Distribusi Pasien BPJS Rawat Jalan Penderita Hipertensi Menurut Jenis Kelamin

\begin{tabular}{|c|c|c|c|c|c|c|c|c|}
\hline \multirow{3}{*}{$\begin{array}{l}\text { Jumlah } \\
\text { Lembar } \\
\text { Resep }\end{array}$} & \multicolumn{6}{|c|}{ Kategori } & & \\
\hline & \multicolumn{2}{|c|}{ Laki - laki } & \multicolumn{2}{|c|}{ Perempuan } & \multicolumn{2}{|c|}{ Umur $<55$} & \multicolumn{2}{|c|}{ Umur $>55$} \\
\hline & $\mathbf{N}$ & n \% & $\mathbf{N}$ & n \% & $\mathbf{N}$ & n \% & $\mathbf{N}$ & n \% \\
\hline 371 & 198 & $53,37 \%$ & 173 & $46,63 \%$ & 110 & 29,64 & 261 & 70,35 \\
\hline
\end{tabular}

Dari tabel 1 (satu) di atas dapat dilihat bahwa dari jumlah sampel resep sebanyak 371, pasien hipertensi dengan jenis kelamin laki - laki adalah yang terbanyak dengan jumlah 198 orang. Ini dimungkin kan karena Faktor gender berpengaruh pada terjadinya hipertensi, dimana pria lebih banyak menderita hipertensi dibandingkan wanita, dengan rasio sekitar 2,29 untuk peningkatan tekanan darah sistolik. Pria diduga memiliki gaya hidup yang cenderung dapat meningkatkan tekanan darah dibandingkan dengan wanita (Depkes, 2010). Sedang wanita sebanyak 173 orang ini dimungkinkan karena wanita yang belum mengalami menopause dilindungi oleh hormon estrogen yang berperan dalam meningkatkan kadar High Density Lipoprotein (HDL). Kadar kolesterol HDL yang tinggi merupakan faktor pelindung dalam mencegah terjadinya proses aterosklerosis. Efek 
Profil Penggunaan Obat Hipertensi pada Pasien BPJS Rawat Jalan di Instalasi Farmasi di Rumah Sakit X Sukabumi

perlindungan estrogen dianggap sebagai penjelasan adanya imunitas wanita pada usia premenopause (Putri, 2018).

Jika dilihat dari umur maka rata - rata umur pasien penderita hipertensi yang adalah pasien BPJS yang datang berobat ke rumah sakit $\mathrm{x}$ sukabumi adalah pasien dengan umur diatas 55 tahun yaitu sebesar 70,35\%, hal ini mungkin disebabkan oleh umur yang sudah menua dan khusus untuk wanita telah memasuki masa menopause sehingga pengaruh estrogen yang selama ini untuk mencegah hipertensi

telah berkurang (Anggraini et al., 2009).

Pemilihan golongan obat hipertensi yang tepat setelah dilakukan anamesis, pemeriksaan dan diagnosis adalah sangat diperlukan dengan tujuan penurunan tekanan darah, mencegah komplikasi, memperbaiki kualitas dan memperpanjang hidup. Pemilihan obat bergantung pada derajad meningkatnya tekanan darah dan keberadaan compelling indications (indikasi yang perlu mendapatkan perhatian) (Tjay \& Rahardja, 2007). Dalam penelitian ini distribusi penggunaan obat hipertensi dapat di lihat pada tabel berikut:

Tabel 2

Distribusi Penggunaan Antihipertensi Berdasarkan golongan

\begin{tabular}{|c|c|c|c|}
\hline \multirow[t]{2}{*}{$\begin{array}{l}\text { Jumlah } \\
\text { LembarResep }\end{array}$} & \multirow[t]{2}{*}{$\begin{array}{c}\text { Golongan } \\
\text { Anti Hipertensi } \\
\end{array}$} & \multicolumn{2}{|c|}{$\begin{array}{l}\text { Persentasi Golongan Anti Hipertensi } \\
\text { yang Diresepkan }\end{array}$} \\
\hline & & $\mathbf{N}$ & $\%$ \\
\hline & Penghambat ACE & 188 & 42,24 \\
\hline & Antagonis kalsium & 150 & 13,71 \\
\hline & $\begin{array}{l}\text { Penghambat reseptor } \\
\text { Angiotensin II }\end{array}$ & 57 & 12,81 \\
\hline \multirow[t]{4}{*}{371} & Beta bloker & 32 & 7,19 \\
\hline & Alpha antagonis & 14 & 3,15 \\
\hline & Nitrat & 4 & 0,9 \\
\hline & Total & 445 & 100 \\
\hline
\end{tabular}

Dari tabel 2 (dua) diatas kita melihat bahwa golongan antihipertensi yang paling banyak digunakan di rumah sakit $\mathrm{x}$ sukabumi yaitu golongan penghambat ACE (captopril, lisinopril, dan ramipril) yaitu sebanyak sebanyak 42,24\%, hal ini disebabkan karena penghambat ACE adalah pilihan kedua setelah penggunaan diuretic dalam terapi antihipertensi, penghambat ACE adalah obat yang berfungsi untuk melemaskan pembuluh darah. Di sisi lain, obat ini dapat membantu mengurangi jumlah cairan yang dapat diserap kembali oleh ginjal. Dengan kedua khasiat tersebut, ACE inhibitor banyak digunakan untuk mengatasi penyakit hipertensi (tekanan darah tinggi), gagal jantung, serangan jantung, sebagian penyakit yang terkait dengan diabetes, serta penyakit ginjal kronis (Formularium Rumah Sakit).

Golongan anti hipertensi yang paling sedikit digunakan adalah golongan nitrat (nitrokaf retard) yaitu sebanyak $0,9 \%$ hal ini mungkin disebabkan karena golongan nitrat lebih banyak digunakan untuk pasien yang mengalami gangguan pada jantung (terapi pilihan pada angina pectoris) dan juga klinis 
jarang menggunakan untuk pasien hipertensi karena efek samping yang timbul akibat penggunaan obat golongan nitrat antara lain: dilatasi arteri akibat nitrat menyebabkan sakit kepala (30-60\% dari pasien yang menerima terapi nitrat), sehingga seringkali dosisnya dibatasi. Efek samping yang lebih serius adalah hipotensi dan pingsan. Refleks takikardia seringkali terjadi. Dosis tinggi yang diberikan jangka panjang bisa menyebabkan methemoglobinemia sebagai akibat oksidasi hemoglobin. Sesekali juga dapat menyebabkan rash (Setiawati \& Suyatna, 2001).

Untuk melihat jenis anti hipertensi yang paling banyak digunakan pada pasien rawat jalan BPJS di rumah sakit $\mathrm{x}$ sukabumi bisa kita lihat pada tabel berikut:

Tabel 3

Distribusi Penggunaan Jenis Antihipertensi yang di resepkan

\begin{tabular}{clcc}
\hline Jumlah Jenis Obat & Jenis Anti & \multicolumn{2}{c}{ Jumlah Jenis Anti Hipertensi } \\
\cline { 2 - 4 } Dalam371 Lembar Resep & Hipertensi & $\mathbf{N}$ & \% \\
\hline & Amlodipin & 147 & 33,03 \\
\hline & Lisinopril & 104 & 23,37 \\
\hline & Captopril & 69 & 15,50 \\
\hline & Candesartan & 57 & 12,80 \\
\hline Bisoprolol & 32 & 7,19 \\
\hline Ramipril & 15 & 3,37 \\
\hline Clonidine & 14 & 3,14 \\
\hline Nitrokaf & 4 & 0,89 \\
\hline Diltiazem & 3 & 0,67
\end{tabular}

Dari tabel 3 (tiga) diatas dapat kita lihat bahwa jenis anti hipertensi amlodipine adalah jenis yang paling banyak digunakan pada pasien hipertensi rawat jalan BPJS rumah sakit x sukabumi yaitu sebesar 33,03\% ini. Karena Amlodipine bisa dikonsumsi secara tersendiri atau dikombinasikan dengan obat lain. Dengan menurunkan tekanan darah, obat ini membantu mencegah serangan stroke, serangan jantung, dan penyakit ginjal. Amlodipine bekerja dengan cara melemaskan dinding dan melebarkan diameter pembuluh darah. Efeknya akan memperlancar aliran darah menuju jantung dan mengurangi tekanan darah dalam pembuluh. Obat ini juga menghalangi kadar kalsium yang masuk ke sel otot halus di dinding pembuluh darah jantung. Kalsium akan membuat otot dinding pembuluh darah berkontraksi. Dengan adanya penghambatan kalsium yang masuk, dinding pembuluh darah akan menjadi lebih lemas (Setiawati \& Suyatna, 2001).

Adanya hipertensi dengan komplikasi menyebabkan pasien mendapatkan obat dalam jumlah jenis yang lebih dari satu. Penggunaan obat dalam jumlah yang banyak dapat menyebabkan timbulnya Drug Related Problem (DRPs) namun kadang penggunaan kombinasi obat perlukan karena alasan medis atau terapi itu sendiri. Pada penelitian ini jumlah item obat hipertensi yang di resepkan untuk pasien rawat jalan BPJS dapat kita amati pada tabel berikut. 
Tabel 4

Jumlah item anti hipertensi perlembar resep pasien rawat jalan BPJS

\begin{tabular}{cclc}
\hline $\begin{array}{c}\text { Jumlah } \\
\text { Lembar } \\
\text { Resep }\end{array}$ & $\begin{array}{c}\text { Jumlah Item } \\
\text { Anti hipertensi }\end{array}$ & \multicolumn{2}{c}{$\begin{array}{c}\text { Persentasi Jumlah Item } \\
\text { Anti } \\
\text { Hipertensi }\end{array}$} \\
\hline & & $\mathbf{N}$ & \% \\
\hline 371 & 1 item & 305 & 82,21 \\
\hline & 2 item & 61 & 16,44 \\
\hline 3 item & 5 & 1,35 \\
\hline
\end{tabular}

Dari tabel 4 (empat) diatas dapat

kita lihat bahwa jumlah item antihipertensi yang paling banyak di resepkan pada pasien hipertensi rawat jalan BPJS di rumah sakit x sukabumi adalah satu item yaitu sebesar $82,21 \%$, hal ini sangat baik disamping menghindari terjadinya DRPs tingkat kepatuhan pasien dalam menjalankan terapi akan semakin tinggi karena jumlah obat yang di minum lebih sedikit sehingga kesetiaan pada terapi lebih tinggi. Selain itu penggunaan obat antihipertensi tunggal atau monoterapi dalam dosis lazim telah mampu mencapai target tekanan darah yang diinginkan.

\section{B. Pembahasan}

Dalam melakukam penelitian ini penulis menggunakna metode deskriptif dan metode kuantitatif dengan data yng digunakan adalah data sekunder yang berasal dari lembaran resep dan data rekam medis pasien hipertensi peserta BPJS di intalasi farmasi Rumah Sakit X Sukabumi priode april - mei 2021.

Dari tabel 1 (satu) di atas dapat dilihat bahwa dari jumlah sampel resep sebanyak 371, pasien hipertensi dengan jenis kelamin laki - laki adalah yang terbanyak dengan jumlah 198 orang. Ini dimungkin kan karena Faktor gender berpengaruh pada terjadinya hipertensi, dimana pria lebih banyak menderita hipertensi dibandingkan wanita, dengan rasio sekitar 2,29 untuk peningkatan tekanan darah sistolik yaitu tekanan saat jantung berkontraksi untuk mempompa darah keseluruh tubuh. Pria diduga memiliki gaya hidup yang cenderung dapat meningkatkan tekanan darah dibandingkan dengan wanita (Depkes, 2010). Sedang wanita sebanyak 173 orang ini dimungkinkan karena wanita yang belum mengalami menopause dilindungi oleh hormon estrogen yang berperan dalam meningkatkan kadar High Density Lipoprotein (HDL). Kadar kolesterol HDL yang tinggi merupakan faktor pelindung dalam mencegah terjadinya proses aterosklerosis. Efek perlindungan estrogen dianggap sebagai penjelasan adanya imunitas wanita pada usia premenopause (Anggraini et al., 2009).

Berdasarkan Dari tabel 2 (dua) diatas kita melihat bahwa golongan anti hipertensi yang paling banyak digunakan di rumah sakit $\mathrm{x}$ sukabumi yaitu golongan penghambat ACE (captopril, lisinopril, dan ramipril) yaitu sebanyak sebanyak 42,24\%, hal ini disebabkan karena penghambat ACE adalah pilihan kedua setelah penggunaan diuretic dalam terapi antihipertensi, penghambat ACE adalah obat yang berfungsi untuk melemaskan pembuluh darah. Di sisi lain, obat ini dapat membantu mengurangi jumlah cairan yang dapat diserap kembali oleh ginjal. Dengan 
kedua khasiat tersebut, ACE inhibitor banyak digunakan untuk mengatasi penyakit hipertensi (tekanan darah tinggi), gagal jantung, serangan jantung, sebagian penyakit yang terkait dengan diabetes, serta penyakit ginjal kronis (Formularium Rumah Sakit).

Golongan anti hipertensi yang paling sedikit digunakan adalah golongan nitrat (nitrokaf retard) yaitu sebanyak $0,9 \%$ hal ini mungkin disebabkan karena golongan nitrat lebih banyak digunakan untuk pasien yang mengalami gangguan pada jantung (terapi pilihan pada angina pectoris) dan juga klinis.

jarang menggunakan untuk pasien hipertensi karena efek samping yang timbul akibat penggunaan obat golongan nitrat antara lain: dilatasi arteri akibat nitrat menyebabkan sakit kepala (30-60\% dari pasien yang menerima terapi nitrat), sehingga seringkali dosisnya dibatasi. Efek samping yang lebih serius adalah hipotensi dan pingsan. Refleks takikardia seringkali terjadi. Dosis tinggi yang diberikan jangka panjang bisa menyebabkan methemoglobinemia sebagai akibat oksidasi hemoglobin. Sesekali juga dapat menyebabkan rash (Setiawati \& Suyatna, 2001).

Dari tabel 3 (tiga) diatas dapat kita lihat bahwa jenis anti hipertensi amlodipine adalah jenis yang paling banyak digunakan pada pasien hipertensi rawat jalan BPJS Rumah Sakit $X$ Sukabumi yaitu sebesar $33,03 \%$ ini, karena Amlodipine bisa dikonsumsi secara tersendiri atau dikombinasikan dengan obat lain. Dengan menurunkan tekanan darah, obat ini membantu mencegah serangan stroke, serangan jantung, dan penyakit ginjal. Amlodipine bekerja dengan cara melemaskan dinding dan melebarkan diameter pembuluh darah. Efeknya akan memperlancar aliran darah menuju jantung dan mengurangi tekanan darah dalam pembuluh. Obat ini juga menghalangi kadar kalsium yang masuk ke sel otot halus di dinding pembuluh darah jantung. Kalsium akan membuat otot dinding pembuluh darah berkontraksi. Dengan adanya penghambatan kalsium yang masuk, dinding pembuluh darah akan menjadi lebih lemas (Setiawati \& Suyatna, 2001).

Dari tabel 4 (empat) diatas dapat kita lihat bahwa jumlah item antihipertensi yang paling banyak di resepkan pada pasien hipertensi rawat jalan BPJS di rumah sakit $\mathrm{x}$ sukabumi adalah satu item yaitu sebesar $82,21 \%$, hal ini sangat baik disamping menghindari terjadinya DRPs tingkat kepatuhan pasien dalam menjalankan terapi akan semakin tinggi karena jumlah obat yang di minum lebih sedikit sehingga kesetiaan pada terapi lebih tinggi. Selain itu penggunaan obat antihipertensi tunggal atau monoterapi dalam dosis lazim telah mampu mencapai target tekanan darah yang diinginkan.

\section{Kesimpulan}

Berdasarkan hasil penelitian yang dilakukan oleh peneliti tentang profil penggunaan obat hipertensi pada pasien BPJS rawat jalan di Instalasi Farmasi simpulkan

Pasien peserta BPJS penderita hipertensi yang berobat rawat jalan di IFRS rumah sakit $\mathrm{x}$ sukabumi yang terbanyak adalah berjenis kelamin laki - laki dengan persentase sebesar $53,37 \%$ sedangkan umur penderita yang terbanyak adalah diatas 55 tahun dengan persentase sebesar 70,35\%.

Golongan anti hipertensi yang paling banyak digunakan Pasien peserta BPJS penderita hipertensi yang berobat rawat jalan di Instalasi Farmasi Rumah Sakit x Sukabumi adalah penghambat ACE dengan persentasi sebesar $42,24 \%$ dan yang paling sedikit digunakan adalah golongan nitrat dengan persentasi sebesar $0,9 \%$. 
Profil Penggunaan Obat Hipertensi pada Pasien BPJS Rawat Jalan di Instalasi Farmasi di Rumah Sakit X Sukabumi

Jenis anti hipertensi yang paling banyak diresepkan adalah amlodipine yaitu sebesar $33,03 \%$, dan yang paling sedikit diresepkan adalah diltiazem yaitu sebesar $0,67 \%$.

Jumlah item jumlah item anti hipertensi yang paling banyak diresepkan adalah satu item atau satu jenis antihipertensi dengan persentase sebesar 82 .

\section{BIBLIOGRAFI}

Anggraini, V., Sudarmonowati, E., Hartati, N. S., Suurs, L., \& Visser, R. G. F. (2009). Characterization Of Cassava Starch Attributes Of Different Genotypes. Starch - Stärke, 61(8), 472-481. Google Scholar

Bustan, M. N. (2007). Epidemiologi Penyakit Tidak Menular. Jakarta: Rineka Cipta, 221. Google Scholar

Depkes, R. I. (2010). Profil Kesehatan Indonesia 2010. Jakarta: Depkes RI. Google Scholar

Erkan, M., \& ARICI DEMIREL, N. (2011). Hata Ve Hile Denetimi: Sermaye Piyasası Kurulu'na Kayıtlı Halka Açık Anonim Şirketlere Ilişkin Düzenlemeler. Muhasebe Ve Denetime Bakış, 33, 2943. Google Scholar

Kandhro, A. J., Mirza, M. A., \& Khuhawar, M. Y. (2008). Capillary Gas Chromatographic Determination Of Methylglyoxal From Serum Of Diabetic Patients By Precolumn Derivatization Using Meso-Stilbenediamine As Derivatizing Reagent. Journal of Chromatographic Science, 46(6), 539-
543. Google Scholar

Kuruvilla, S., Sadana, R., Montesinos, E. V., Beard, J., Vasdeki, J. F., De Carvalho, I. A., Thomas, R. B., Drisse, M.-N. B., Daelmans, B., \& Goodman, T. (2018). A Life-Course Approach To Health: Synergy With Sustainable Development Goals. Bulletin Of The World Health Organization, 96(1), 42. Google Scholar

Organization, W. H. (2019). Global Status Report On Alcohol And Health 2018. World Health Organization. Google Scholar

Putri, D. A. (2018). Analyzing Factors Influencing Continuance Intention Of EPayment Adoption Using Modified UTAUT 2 Model. 2018 6th International Conference On Information And Communication Technology (Icoict), 167-173. Google Scholar

Riskesdas. (2013). RISKESDAS 2013. In Jakarta Kementeri Kesehat RI (Vol. 6). Google Scholar

Setiawati, A., \& Suyatna, F. D. (2001). Farmakologi Dan Terapi: Obat Antiangina. Edisi IV. Google Scholar

Sugiyono, M. P. P., \& Kuantitatif, P. (2012). Kualitatif, Dan R\&D, Bandung: Alfabeta. Cet. VII. Google Scholar

Tjay, T. H., \& Rahardja, K. (2007). ObatObat Penting: Khasiat, Penggunaan Dan Efek-Efek Sampingnya. Elex Media Komputindo. Google Scholar

Copyright holder:

Wisma Ismaya, Rida Emelia (2022)

First publication right:

Jurnal Health Sains

This article is licensed under:

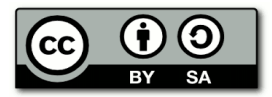

